\title{
CrimRxiv
}

\section{The governance of female drug users:Women's experiences of drug policy}

Natasha Du Rose

Published on: Mar 04, 2022

DOI: $10.21428 / \mathrm{cb} 6 a b 371.83$ deaefe

License: Creative Commons Attribution 4.0 International License (CC-BY 4.0). 
